Relations industrielles

Industrial Relations

\title{
André Beaucage, Syndicats, salaires et conjoncture économique
}

\section{Michel Grant}

Volume 46, numéro 4, 1991

URI : https://id.erudit.org/iderudit/050727ar

DOI : https://doi.org/10.7202/050727ar

Aller au sommaire du numéro

Éditeur(s)

Département des relations industrielles de l'Université Laval

ISSN

0034-379X (imprimé)

1703-8138 (numérique)

Découvrir la revue

Citer ce compte rendu

Grant, M. (1991). Compte rendu de [André Beaucage, Syndicats, salaires et conjoncture économique]. Relations industrielles / Industrial Relations, 46(4), 869-870. https://doi.org/10.7202/050727ar

Tous droits réservés @ C Département des relations industrielles de l'Université Laval, 1991
Ce document est protégé par la loi sur le droit d'auteur. L’utilisation des services d'Érudit (y compris la reproduction) est assujettie à sa politique d'utilisation que vous pouvez consulter en ligne.

https://apropos.erudit.org/fr/usagers/politique-dutilisation/ 
the 1980s. In particular, a number of chapters are worthy of mention. Gardner's chapter on union strategy provides an interesting approach to the understanding of union behaviour. The model is based on the notion of choice rather than determinism in union activity. This choice has definable boundaries and in the formulation of strategy a number of external and internal factors impinge upon the decision making process. For readers interested in a concise description and analysis of union history this is provided in Hagan's chapter on the Australian union movement 1850-1987. Equally, at the micro level Rimmer's chapter on workplace unionism provides a detailed analysis of shop floor union organisation in the period 1917-1987. Several other chapters provide the reader with some of the uniqueness of Australian unions and the issues they pursued in the 1980s. These are Deery's chapter on union aims and methods, Griffin and Giuca's contribution on the formation of one peak labour organisation, Quinlan's interesting and well researched chapter on the relationships between migrants and trade unions, and the chapters on wages policy and technological change by Tiecher and Deery respectively. Thus, for both the student and others interested in Australian unionism the book provides a valuable collection of contemporary readings on selected aspects of Australian trade unions.

Notwithstanding the above, this reviewer has three major criticisms of the book. First, the book is a collection of individual papers with little or no attempt to unite the contributions or to place them within an overall theoretical perspective. The chapter on Strategic Unionsim could have possibly served this purpose but clearly considerably more work is needed in developing a theoretical perspective relevant to Australian Unionism. Second, the book tends to be somewhat dated and whilst individual chapters address a number of issues facing trade unions in the 1980's the book as a whole does not capture the dynamic nature of trade unions during this period. Indeed, a number of important issues such as declining trade union density, the concept of strategic/political unionism, the changing role and growing influence of the Australian Council of Trade Unions, the increasing pace of trade union amalgamations, and the actual operations and influence of trade unionism at the workplace are neglected. Given the shift towards enterprise bargaining during the past four years this last omission is a severe flaw in the book.

Finally, and related in part to the second criticism, the book seems driven, at least to some degree, by issues that are of importance to the Australian Council of Trade Unions. This approach not only neglects issues of importance to individual unions or unions at the workplace, such as the restructuring of the union movement, but it fails to make a critical assessment of the path unionism has taken in Australia and whether such an approach is advantageous for union members.

John BENSON

University of Melbourne

Syndicats, salaires et conjoncture économique, par André Beaucage, Québec, Presses de l'Université du Québec, 1989, 126 pages, ISBN 2-7605-0532-4

L'auteur cherche dans ce volume à analyser l'évolution des politiques sous-tendant les demandes syndicales lors des rondes de négociation entre 1971 et 1983 entre le gouvernement du Québec et le Front commun FTQ-CEQ-CSN. L'approche retenue pour l'analyse est surtout qualitative. Il s'agit d'évaluer «si les grands objectifs des politiques salariales du Front commun se sont traduits dans la réalité, pour l'ensemble de la période 1971-1983, par des résultats compatibles avec l'orientation de ces grands objectifs» (p. 4). 
Après le premier chapitre introductif, le second chapitre de l'ouvrage situe le contexte économique à l'intérieur duquel se sont déroulées les quatre rondes de négociation dans les secteurs public et parapublic. Il utilise des indicateurs généraux de conjoncture économique tels les taux de chốmage; il présente succintement des données sur l'évolution des effectifs dans les secteurs public et parapublic; un examen du contexte de l'époque étudiée aurait été incomplète sans une référence à la radicalisation du discours idéologique des centrales syndicales pendant les années 1970.

Au chapitre 3, André Beaucage définit la notion de politique salariale comme «une rationalisation plus ou moins explicite et élaborée de l'évolution des niveaux de salaire et de leur structure à partir d'objectifs et de principes généraux ou spécifiques et de leurs modalités d'application». Ce chapitre porte sur la nature, la portée et la signification de cet exercice syndical. À partir d'une analyse des documents et des discours syndicaux, l'auteur identifie les trois objectifs suivants dont la constance s'est maintenue pour la période de référence: salaire égal pour les tâches semblables; réduction des écarts entre le taux maximum et le taux minimum des échelles salariales; rythme d'augmentation générale des salaires permettant aux salariés de participer à l'enrichissement collectif. L'auteur souligne que, au plan du discours, les promoteurs syndicaux de cette politique salariale attribuent à cette dernière une force d'entraînement sur les conditions de rémunération dans l'ensemble de l'économie. Le Front commun se considère comme une locomotive et cherche à influencer les forces du marché plutôt que d'être à leur remorque et plutôt que de se satisfaire de négocier des taux comparables à la moyenne observée dans le secteur privé. Cette approche contraste avec la politique salariale du Front commun en 1982 qui la redéfinit "comme un moyen pour freiner la baisse de la demande globale par le maintien du rythme des dépenses publiques et ainsi compenser en partie le ralentissement marqué de l'activité économique du secteur privé».

Le chapitre suivant présente les résultats d'une analyse préliminaire de l'impact de la politique salariale du Front commun sur la hiérarchie des salaires et sur le rythme de croisière des taux dans les secteurs de l'éducation, de la santé et des services sociaux. Pour l'auteur, il s'agit d'une façon de mesurer l'efficacité ou le degré de succès des stratégies syndicales déployées pour réaliser les objectifs définis dans la politique salariale. Beaucage cherche donc à évaluer la transformation de la structure salariale à la lumière des objectifs syndicaux pour évaluer le degré de réalisation de ces derniers. Il utilise une base d'observation représentant $51 \%$ des titres d'emploi sous l'influence directe du Front commun. Ainsi, pour mesurer l'évolution des écarts salariaux, il recourt à un coefficient mesurant la dispersion relative des salaires par rapport à la moyenne. L'auteur conclut que les résultats observés permettent de soutenir que le Front commun a, durant cette période entre 1971 et 1983 , réalisé deux de ses objectifs: (1) la réduction des écarts relatifs des taux de salaire et (2) l'enrichissement positif pour chaque salarié. L'auteur ajoute que les recherches et observations ne permettent pas de conclure que les ententes salariales du secteur public ont eu un effet «locomotive» sur les salaires du secteur privé. Il laisse entendre, à la page 86 , que la croissance des bas salaires fut plus rapide dans le secteur public. Il conclut que le Front commun n'aurait pas eu «l'impact souhaité sur la rémunération des travailleuses qui occupent en majorité des emplois moins rémunérés du secteur privé non syndiqué».

Michel Grant

Université du Québec à Montréal 